\title{
Analysis of civil society movements: the case of construction of geothermal power plant in Mount Talang Area
}

\author{
Hidayatul Fajri ${ }^{1, *}$, Qori Pebrial Ilham $^{2}$, and Historis Soterman Halawa ${ }^{1}$ \\ ${ }^{1}$ Universitas Negeri Padang, Department of Public Administration, 25132 Padang, Indonesia \\ ${ }^{2}$ Institut Teknologi Sumatera, Department of Forest Engineering, 35363 South Lampung, Indonesia
}

\begin{abstract}
Geothermal energy is seen as one of the potential energy sources developed at present and in the future. In addition, geothermal energy is also claimed as environmentally friendly energy. However, the development and utilization of this energy are not fully accepted by all parties. Discourse on renewable and environmentally friendly energy clashes with issues of social injustice on a broader scale the problem of humanity and the environment. This study aims to analyze the movements developed by civil society in advocating the interests of the community in the development of geothermal energy in the mountain region of TalangBukit Kili. Our study takes the form of a case study focusing on the actors involved in the movement. This study uses in-depth semi-structured interviews. The results of the study show that movements are formed by several elements, namely; Non-Government Organization (NGO), students, civil society, and academics. These elements then form a different movement model. The movement developed by students and civil society is grouped as a new social movement model.
\end{abstract}

\section{Introduction}

Looking for energy sources that are environmentally friendly is one of the goals of the principle of sustainable development. One potential energy source is geothermal. Geothermal energy is not a familiar energy in Indonesia even though it has enormous energy potential. It even becomes one of the largest energy in the world. The owned potential about $28.910 \mathrm{GW}$ spreads over 312 locations in several islands in Indonesia [1]. However, the utilization of the energy is still less than $5 \%$ of the potential that exists with an installed capacity of $1533.5 \mathrm{MW}$ [2].

Utilization of geothermal has become a global discourse and many people consider this energy as one of the energies of the future. The energy that can replace the dependence on energy derived from fossil fuels, such as petroleum and coal. Some studies suggest that geothermal energy is green energy [3] That does not have emissions (zero of emissions) [4], and sustainability [5]. Although some studies also show that geothermal energy has an environmental impact (related to the impact categories commonly used in life cycle

\footnotetext{
${ }^{*}$ Corresponding author: hidayatulfajri@,fis.unp.ac.id
} 
assessments) such as; reservoir characteristics, geothermal fluid chemistry, power generation technology, type of emissions of the life cycle inventory, and data availability [6].

Geothermal potential is addressed by the government that is planning to build some new points of utilization of geothermal energy, one of which is located in the area of Bukit KiliMount Talang in West Sumatra. The area is on a plan for the establishment of the geothermal power plant with a power of $20 \mathrm{MW}$. In 2016, the government won the PT Hitay as the company that will carry out exploration and exploitation in the area. The government awarded exploration rights for 7 years and the exploitation for 25 years with an offer to extend the contract back.

However, the plan received a rejection from communities around Bukit Kili-Mount Talang, especially the people in Nagari Batu Bajanjang village in which their land is used as the first point of geothermal exploration activities. The resistance movement is then amplified by civil society in West Sumatra, such as communities, students, NonGovernmental Organizations (NGO), or those who are sympathetic to the community. Support for the more resistance movement is massively increasing especially since clashes between the people of Nagari Batu Bajanjang with The PT Hitay in November 2017 which led to the determination of 12 people as the suspects as a result of car burning from a company in the clash.

In this study, we used the first definition toward the civil society, ie, a non-profit entity either formal or informal which can include or represent a set of interest groups associated with political, religious, social, economic, and $[7,8,9]$. Meanwhile, to show the relationship between civil society and social movements, we use an analysis [10]. In addition, [11] illustrated that the civil society and social movements are in the same room. Further explained that the civil society is the battleground of social forces against the state and the market that aims to change the dominant force. Because in this definition, the state is seen as a form of Weberian state whose bureaucracy agencies have the ability to monopolize the means of violence. Thus, to compensate the problem, the civil society through activities of social movements put forward demands on the country (and business) [12].

But from these studies, we see that civil society is still defined as an association of special interest groups when there is a tendency to move more liquid without considering the background of their interest groups. In addition, civil society movements are not always in the form of resistance to oppression or suppression of state power as a result of the marriage of power between state and business. However, there are other things that the reason for the movement; the values that are more universal such as human and the environment as well as the discourse of the values of sustainable development.

Therefore, this study aimed to analyze the civil society movement in geothermal energy development activities in the area of Bukit Kili-Mount Talang, especially to see their perceptions of the development of geothermal energy which become the basis of their refusal, forms, and strategies of the movement that they do. Thus, it can be used as an overview of the situation for policymakers and other stakeholders.

\section{Materials and methods}

This study employed a qualitative approach with the study-case design. We consider it the most suitable for analyzing complex social phenomenon because it allows for the establishment of relations between the events of practical and theoretical abstraction [13]. It also has the advantage of giving the flexibility to identify new variables. Data collection begins by analyzing the literature, the news in print and online media, social media, and documents that aim to identify the parties involved directly in the refusal movement of the utilization of geothermal energy. Furthermore, this study conducted an interview with a 
form of in-depth semi-structured interviews with individuals or actors included in the category that has been identified. [14] stated that the semi-structured interview is an appropriate tool to collect information from an individual perspective, which focuses on the experiences, beliefs, and perceptions.

Topics for the interview includes questions such as; the chronology of the movement, their perception of the movement and the development geothermal energy plant, the movements they have done and why, the media they use, current conditions, their movement form of collaboration with other parties, what to do next and the alternatives they offer. The question then is developed so that the informant answered all the topics of the interview. All interviews were conducted from May to early August 2018. Furthermore, the information that has been collected and analyzed thematically to get an answer from this study.

\section{Results and discussion}

\subsection{Overview of social movements: from society to civil society}

The first rejection begins when the government unilaterally decided to provide concessions of the development of thermal energy in the areas around Mount Talang to PT Hitay Daya Energy at the end of 2016. Granting processing was marked by the Decree of the Minister of Energy and Mineral Resources (EMR) No. 7257 K / 30 / MEM / 2016 followed by the granting of the Investment Coordinating Board No. 2/1 / IPB / PMA / 2017 for the activities of exploration and exploitation of geothermal that will be used as geothermal power plant powered $20 \mathrm{MW}$. Granted exploration permits covering 27,000 hectares covering 4 districts and 22 villages in Solok. Thus, the area was later named as the Geothermal Working Areas Mount Talang-Bukit Kili.

The starting point of development is centered in Nagari Batu Bajanjang. In June 2017, the Government through the Nagari government began informing the public about the development of geothermal energy projects. The information stated that the construction will be carried out at least two months since the socialization. This then raises the pros and cons of society. In the same month, the people of Nagari Batu Bajanjang who disagree form a community called HIMAPAGTA (Community Association of Lovers of Mount Talang). This group later became the driving force of early rejection of geothermal energy development.

Society then appealed to Padang Law Aid Agency (LBH) to provide legal protection and the Indonesian Environmental Forum of West Sumatra (WALHI) to undertake an environmental assessment of the development of it. Thus, both of them can be regarded as civil society groups, outside the village community, who first took part in the movement.

Triggered by HIMAPAGTA, people are starting to demonstrate rejection of geothermal projects. The demonstration was first performed on September 13, 2017, which was followed by a larger demonstration on October 2, 2017, involving thousands of people (See Picture 1). Demonstrations conducted around the regent office of Solok Regency with the demands for an audience with the Regent who unfortunately did not materialize and ultimately the audience was only represented by Vice Regent. 


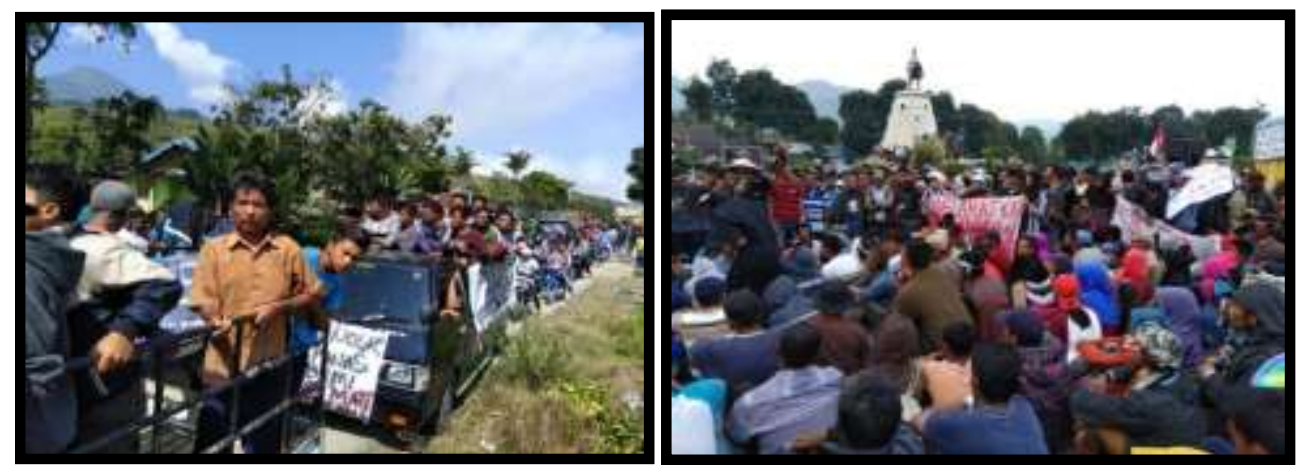

Fig. 1. Demonstrations carried out by communities around the Tlang Mountain and HIMAPAGTA.

The peak of escalation occurred on November 20, 2017. When the PT Hitay Daya Energy, which was escorted by army officers, wanted to get into the site of the development plan. They were then confronted by the society, who then led to the burning of a vehicle of PT Hitay. The act then made 12 people declared as suspects, with 3 people were arrested and 9 others are included in the list of Searched people. It then made the rejection movement had a vacuum for a while because the 12 suspects are the key actors of the movement, although evidence of their involvement in the case is still in the legal process.

Clashes broke out again on March 21, 2018, when PT Hitay, escorted by dozens of military personnel, police and municipal police along with representatives of Solok regency government to review the location of the project. The clashes led to 7 injured people, where two of them are children and 3 are women (some parties mention what happened actually was a clash between the pro-development community with the counter while others assess violence involving apparatus). Padang Law Aid Agency together with Indonesian Environmental Forum of Sumatera Barat then addressed this by issuing a press statement, the four main demands, namely; 1) evaluation of development projects, 2) termination of criminalization, 3) an investigation into the violence, 4) require the involvement of National Commission of Human rights, National Commission of women and the National Commission of Child Protection to participate in the investigation.

The clashes which caused injuries in the society became the starting point to the involvement of various civil society in the movement. They felt sympathetic to the conditions experienced by the people of Batu Bajanjang. The participation of civil society then made widespread movements and the issues brought became more diverse. Before the civil society joined in a broader scale, the movement is localized only on the issue of public rejection of the development of geothermal energy. After that, the issue becomes more widely grown, like the humanitarian, violence, deprivation, environmental sustainability, and social involvement in the policy.

Although the movement issue is largely expanding, the main actor moved. The Movement was later taken over by students, civil society, and NGOs. Actor displacement of the movement makes the changes into the form of movement which is characterized by a more fluid movement form in the absence of the parties that dominate in the movement. The carried-out actions are more likely to become collaborative actions. In addition, the actions are no longer in the form of confrontation, but rather in the form of development discourse. The location of the movement is also no longer centered in Nagari Batu Bajanjang but moves to cities in West Sumatra, such as Padang, Bukittinggi, Solok, as well as the use of online media. This will be discussed in point 3.2. 


\subsection{Civil society: perception, action, and model}

The researchers in this study sought to identify the civil society involved in the movement. Although this categorization results in a simplification because often, the actors involved do not bring their background. It becomes something unavoidable since we aim to see the elements which caused the movements after the transfer of the actors from society to civil society. Additionally, this identification makes it easier to see their perception toward geothermal energy development in the area of Mount Talang.

Identification that we carried out illustrates that the movements were formed by the four elements, namely NGOs, students, civil society, and academia. NGOs playing a role in this movement is the Padang Law Aid Agency, West Sumatra, and Conscience Women. Besides, the elements of students are formed from various universities in West Sumatra. Elements of these students were divided into two, the students acting personally and students acting through BEM (Student Executive Board). Students who act personally tend to be more liquid and autonomous to get out and get into motion. In this study, we name such students as "student cares about Mount Talang". While students belonging to the BEM, in this case, are more rigid in the sense that they are dependent upon the direction of their organization. This difference then also affects the form of options for action that they did (see Table 1). The third element is the civil society. Civil society involved in a community that has been there and then joins the movement after the occurrence of violence against society. Forming elements of the last movement are Academia coming from Andalas University. Academia involvement in the movement is more like their cooperation with NGOs, especially WALHI in preparing the study as an input to the policy of the government. More details can be seen in Table 1 along with their perception of the development of geothermal energy in the Mountain area of talang and the actions they have taken:

Table 1. Perception and action of civil society in construction of geothermal power plant in Mount Talang Area.

\begin{tabular}{|c|c|c|c|}
\hline \multicolumn{2}{|c|}{ Civil society } & Perception & \multirow[b]{2}{*}{\begin{tabular}{l}
\multicolumn{1}{c}{ Action } \\
- Advocating society in legal \\
aid \\
- Sending paralegal to help \\
the society.
\end{tabular}} \\
\hline NGO & LBH Padang & $\begin{array}{l}\text { Geothermal Energy } \\
\text { Construction Policy has } \\
\text { infringed society's rightsfor not } \\
\text { providing participation space so } \\
\text { that it needs a review of permits } \\
\text { andregulations. }\end{array}$ & \\
\hline & $\begin{array}{l}\text { WALHI } \\
\text { Sumatera } \\
\text { Barat (West } \\
\text { Sumatera) }\end{array}$ & $\begin{array}{l}\text { The government must provide } \\
\text { an explanation based on a } \\
\text { credible assessment of the } \\
\text { environmental impact of } \\
\text { geothermal } \\
\text { development. }\end{array}$ & $\begin{array}{l}\text { - Cooperating with } \\
\text { Academia to discuss about } \\
\text { the social, economic, and } \\
\text { enviromental impacts. } \\
\text { - Conducting } \\
\text { accompaniment activities } \\
\text { for the society }\end{array}$ \\
\hline & $\begin{array}{l}\text { Conscience } \\
\text { Women }\end{array}$ & $\begin{array}{l}\text { Local governments } \\
\text { enterprises to have } \\
\begin{array}{l}\text { violence to women } \\
\text { children. }\end{array}\end{array}$ & $\begin{array}{l}\text { - Cooperating with WALHI } \\
\text { to conduct trauma healing } \\
\text { to the society, especially } \\
\text { women and children }\end{array}$ \\
\hline $\begin{array}{l}\text { University } \\
\text { students }\end{array}$ & $\begin{array}{l}\text { Students } \\
\text { Concerned } \\
\text { Mount Talang } \\
\text { (composed of } \\
\text { various } \\
\text { universities in } \\
\text { West }\end{array}$ & $\begin{array}{l}\text { - } \text { The Government has } \\
\text { committed violence and } \\
\text { criminalization toward } \\
\text { society that rejects } \\
\text { Geothermal } \\
\text { Construction } \\
\text { - No informational explanation }\end{array}$ & $\begin{array}{l}\text { - Conducting campaigns } \\
\text { through creative actions } \\
\text { (murals, poetry readings, } \\
\text { painting, theater, speeches) } \\
\text { in some places, working } \\
\text { with the community } \\
\text { Belanak, North Shelter, }\end{array}$ \\
\hline
\end{tabular}




\begin{tabular}{|c|c|c|c|}
\hline & Sumatra) & $\begin{array}{l}\text { on the impact of geothermal } \\
\text { energy Construction } \\
\text { - Geothermal energy } \\
\text { construction does not involve } \\
\text { the community. }\end{array}$ & $\begin{array}{l}\text { Action Kamisan, Coffee } \\
\text { Shack, and Sumatra Senja } \\
\text { - Distribution of posters, } \\
\text { leaflets and pamphlets in } \\
\text { public spaces, working } \\
\text { with the community. } \\
\text { - Disseminate information in } \\
\text { online media. } \\
\text { - Assistance to the society in } \\
\text { collaboration with LBH } \\
\text { and WARSI }\end{array}$ \\
\hline & $\begin{array}{l}\text { BEM Alliance } \\
\text { West Sumatra }\end{array}$ & $\begin{array}{l}\text { - There was violence against } \\
\text { thesociety. } \\
\text { - The government must hold a } \\
\text { dialogue with the loca } \\
\text { lsociety }\end{array}$ & $\begin{array}{l}\text { - Conducting a } \\
\text { demonstration in front of } \\
\text { the Governor's Office }\end{array}$ \\
\hline $\begin{array}{l}\text { Civil } \\
\text { community }\end{array}$ & $\begin{array}{l}\text { - Gubuk } \\
\text { Kopi (The } \\
\text { coffee } \\
\text { shack) } \\
\text { - Aksi } \\
\text { Kamisan } \\
\text { (Action } \\
\text { Kamisan) } \\
\text { - Shelter } \\
\text { Utara } \\
\text { (North } \\
\text { Shelter) } \\
\text { - Belanak } \\
\text { (mullet) } \\
\text { - Sumatera } \\
\text { Senja (Dusk } \\
\text { Sumatra) } \\
\text { - Menace } \\
\text { Space } \\
\text { (Space } \\
\text { Menace) }\end{array}$ & $\begin{array}{l}\text { - Governments do not socialize } \\
\text { the impacts of the } \\
\text { development of geothermal } \\
\text { energy openly. } \\
\text { - Violence and criminalization } \\
\text { of society by the government } \\
\text { and companies. } \\
\text { - People are not involved in the } \\
\text { policy process } \\
\text { - The government did not } \\
\text { involve the society in the } \\
\text { policy process }\end{array}$ & $\begin{array}{l}\text { - Conducting campaigns } \\
\text { through creative actions } \\
\text { and distribution of posters, } \\
\text { leaflets and pamphlets with } \\
\text { students and the society. } \\
\text { - Disseminate information } \\
\text { through online media. }\end{array}$ \\
\hline Academics & $\begin{array}{l}\text { Andalas } \\
\text { University }\end{array}$ & $\begin{array}{l}\text { - Companies and government } \\
\text { do not provide social and } \\
\text { economic assessment of the } \\
\text { environmental impacts that } \\
\text { will result from the } \\
\text { contruction of geothermal } \\
\text { energy. }\end{array}$ & $\begin{array}{l}\text { - Arraging Policy Brief } \\
\text { together With WALHI }\end{array}$ \\
\hline
\end{tabular}

Perception and action from civil society as seen from table 1 is not a form created. But it was born from the awareness of the actors in seeing the conditions that exist. This can be seen from the interviews we conducted with them, parties from "Gunung Talang caring students" and the civilian community answered exactly the same thing that they were driven by awareness of the conditions that occur in society. The two dominant words we get from the reason for their participation in the action are "humanity" and "environment". This shows that the movement is no longer localized on the issue of "completely rejecting the construction of geothermal power plant", which tends to be the core of the discourse of previous community movements. 
Our analysis then tried to look at the pattern of this civil society movement, we saw that there were two forms of movement that were seen, namely the movement which tended to be fluid when those who initiated the movement were elements of "students concerned about Gunung Talang" and "Civil Communities". And movements that tend to be rigid if the initiators are other elements, such as NGOs, and Students from the BEM Alliance. The use of liquid and rigid here is not used as a positive or negative connotation, but only to describe the involvement of actors, the structure of the movement, the chosen action.

We saw that the movement initiated by "students concerned about Mount Talang" and "Civil Communities" actions they did tend to take the form of creative and sympathetic actions. The purpose of their action is to capitalize more on issues in the public space to become more massive so as to form a public discourse about the need to re-evaluate the development of geothermal energy in the Gunung Talang-Bukit Kili area (See Picture 2) The spectrum of movement in the sense of direction of movement is no longer inward (centripetal) which aims to strengthen the line but outward (centrifugal) the actors involved remain decentralized and without the central actor that determines the direction of the movement.
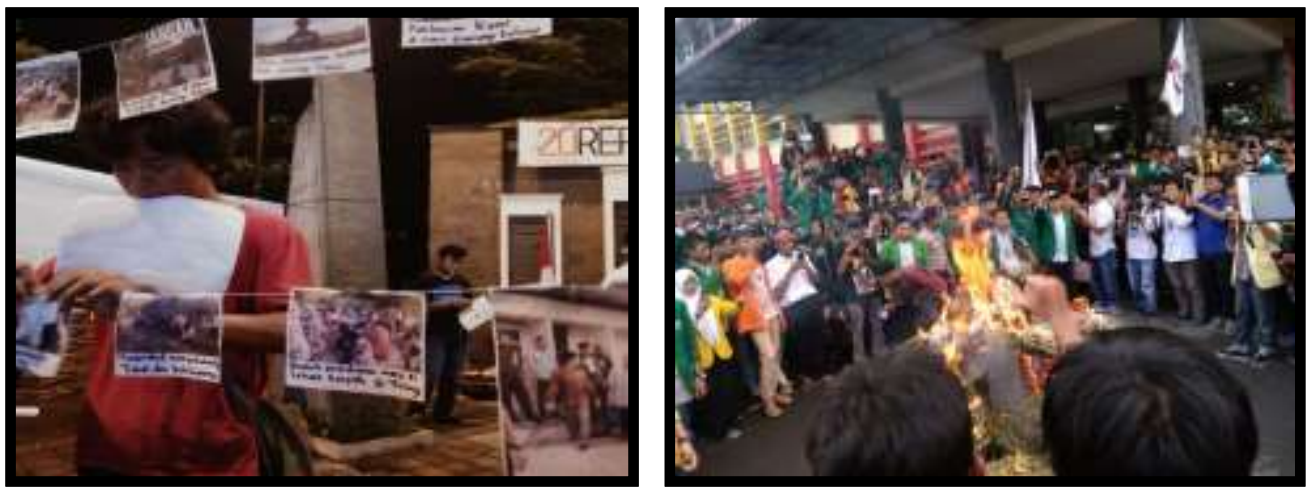

Fig. 2. Actions taken by Students Concerned Mount Talang and Civil Community (left); BEM Alliance West Sumatra (Right).

The tendency of this form of movement then made us classify the movements of "Gunung Talang caring students" and "Civil Communities" as a form of new social movements. Although it does not yet have great power, it can be said as an embryo from the birth of a new social movement in West Sumatra. Something based on our unprecedented observations in West Sumatra.

The study states that the characteristics of a new social movement lie in ideology and goals that are not political, tactics that do not use formal political channels, non-rigid movement structures, participants from the educated middle class, and the diversity of ideas $[15,16,17]$. If seen then, the Movement carried out by "students concerned about Mount Talang" and "Civil Society" is no longer a movement that is influenced by an ideology because their goals do not have a practical political tendency. The tactics used are also tactics that aim to build public discourse, such as sympathetic and creative invitations carried out in public spaces and online media. The structure of the movement they built was also not rigid, open, and non-hierarchical because of the absence of organization, background, and leaders in the movement. The participants came from the middle class and were educated because the core of the movement was formed by students and civil society who on average also came from students and workers. And the ideas they brought also varied as seen from their perceptions in table 1 . 
On the other hand, movements from NGOs, BEM alliances and Academics cannot yet be called the New Social Movement, because they are still limited to structures that tend to be formal. The tactics used are not yet in the form of tactics that aim to build public discourse because they are still channeled to formal political channels through dialogue with the DPRD and policy input to the provincial government. Even so, their movements cannot be categorized as old social movement models. Their limitations are to actualize more movement models to their attachment to a permanent and structured organization.

\section{Conclusion}

Social movements carried out by civil society in West Sumatra emerged as a response to repressive actions from the government against the people of Nagari Batu Bajanjang. Civil society then forms actions that aim to build public discourse and also provide policy input to the government. Although, the movement has not been able to bring the government into negotiations, what they have done has made a discourse on the development of geothermal energy in the area of Mount Talang-Bukit Kili starting to enter public spaces. Moreover, the actions they did in the movement were very varied, not just stuck in one form.

Finally, we realized that the separation of the form of movement that we carried out in this article contained a simplification because between the constituent elements of their movement were networked within the coalition to conduct advocacy. However, it cannot be avoided to understand and analyze the emergence of the movement of civil society in West Sumatra in advocating for the interests of the people affected by the development of geothermal energy in the area of Mount Talang-Bukit Kili.

\section{References}

1. S. M. Bina, S. Jalilinasrabady, H. Fujii, N. A. Pambudi. J. Re. \& Sus. En. Rev, 93 (2018)

2. N. A. Pambudi. J. Re \& Sus. En. Rev, 81 (2018)

3. C. Marieni, J. Prikryl, E. S. Aradottir, I. Gunnarsson, A. Stefansson. Int. J. of G. G. Con, 77 (2018)

4. D. Bonalumi, P. A. Bombarda, C. M. Invernizzi. En. Pro, 126 (2017)

5. R. Shortall, B. Davidsdottir, G. Axelsson. J. Re. \& Sus. En. Rev, 44 (2015)

6. C. Tomasini-Montenegro, E. Santoyo. J. Ap. Th. Eng, 114 (2017)

7. L. Salamon, H. Anheier. Social Origins of Civil Society (John Hopkins University Institute for Policy Studies: Baltimore, 1996)

8. E. T. Boris. The Nonprofit Sector in the 1990s. (Indiana University Press: Bloomington, 1999)

9. R. DeHoog, H. Racanska. Democratization, Civil Society, and Nonprofits (The Aspen Institute: Washington DC, 1999)

10. J. P. Comas, J. P Shrivastava, E. Martin. Journal of Management Inquiri, 24 (2015)

11. C. Houg. J. Org. St, 34 (2013)

12. P. Kirbi. Ir. J. of Soc, 2 (2010)

13. R. Stake. Qualitative Case Study (Sage, Thousand Oaks, 2005)

14. G. Guest, E. Namey, M. Mitchell. Collecting Qualitative Data: a field manual for applied research (2013) 
15. E Larana et.,al., New Social Movements: From Identity to Ideology (Temple University Press, Philadelphia, 1994)

16. N. A. Pichardo. J. An. Rev. of Soc, 23 (1997)

17. L. d'Anjou, J. V. Male. Mob.: An Int. J, 3 (1998) 